УДК 577.2

DOI: 10.33184/spbgb-2021-09-21.23

\title{
Оценка влияния стевиозида на прорастание семян и рост проростков Rhodiola rosea в культуре in vitro
}

\author{
(C) А.С. Киселева, У.А. Галиханова* \\ Казанский государственный университет \\ Россия, Республика Татарстан, 420008 г. Казань, улица Кремлевская, 18. \\ *Email: uliana_ogo@mail.ru
}

Цель работы заключалась в оценке особенностей проростков родиолы розовой, обработанных стевиозидом, при введении их в культуру in vitro. Установили, что обработка стевиозидом $\left(10^{-8} \mathrm{M}, 34\right)$ сокращает время прорастания семян родиолы розовой, повышает всхожесть семян, стимулирует рост надземной и подземной части проростков. Показано, что полученные in vitro растения родиолы розовой из обработанных стевиозидом проростков фрормируют большее количество листьев и корней, чем контрольные растения.

Ключевые слова: родиола розовая, Rhodiola rosea, стевиозид.

Rhodiola rosea L. (родиола розовая) - редкое лекарственное растение, благодаря уникальному биохимическому составу обладает стимулирующими и адаптогенными свойствами, высокой антиоксидантной активностью.

В связи с тем, что лекарственным растительным сырьем являются корневища с корнями, в настоящее время из-за их неконтролируемого сбора произошло резкое сокращение численности и истощение природных популяций растения. Вид родиола розовая занесен в Красные книги отдельных регионов и Российской Федерации. Кроме того, существует целый ряд факторов, препятствующих восстановлению разреженных зарослей родиолы: медленный рост корневища (восстановление зарослей в течение 5-10 лет), очень низкая семенная всхожесть (до 30\%), необходимость длительной стратифрикации, высокий процент гибели проростков первого года, сокращение численности женских особей в большинстве популяций $[1,2]$.

Одним из решений данной проблемы является вегетативное размножение родиолы розовой, в том числе с использованием биотехнологических подходов, выращивая растения in vitro в лабораторных условиях. Культивирование in vitro позволяет не только сохранять природные популяции, но и является одним из альтернативных источников получения лекарственного сырья.

По литературным данным установлено, что применение стратификации и регуляторов роста повышает энергию прорастания и всхожесть семян, способствует уменьшению числа погибших проростков у родиолы розовой [3]. Исследования [4,5] свидетельствуют о том, что энт-каурановый гликозид - стевиозид растения Stevia rebaudiana может быть использован в качестве регулятора роста и развития растений, повышая активность альфа-амилазы и усиливая процессы роста надземной и подземной части проростков озимой и яровой пшеницы, семена которой перед посадкой были обработаны раствором стевиозида $\left(10^{-8} \mathrm{M}, 24 \mathrm{4}\right)$. 
В связи с этим цель работы заключалась в оценке особенностей проростков родиолы розовой, обработанных стевиозидом, при введении их в культуру in vitro.

Объектом исследования служили проростки родиолы розовой, выращенные из семян (сбор 2019 г.), приобретенных в питомнике Анисимова Г. П. (г. Томск).

Эксплантами для введения в культуру in vitro служили проростки с корнями родиолы розовой, полученные из стратифицированных семян, с дополнительной обработкой раствором стевиозида.

Предпосевная обработка семян включала стратификацию в холодильной камере в течение 30 дней при температуре $+4^{\circ} \mathrm{C}$ на фрильтровальной бумаге. Семена перед посадкой замачивали на 24 ч. Для подбора наиболее эффрективной схемы обработки родиолы стевиозидом часть семян обрабатывали исследуемым веществом в концентрации $10^{-8}$ М в течение разного времени: $3,6,12,24$ ч. Контрольные семена замачивали на 24 часа в водопроводной воде. Проростки выращивали на фильтровальной бумаге в чашках Петри в течение двух месяцев в растильне (фотопериод 16/8-часовой цикл свет/темнота, интенсивность освещения 8 клк, температура $22 \pm 1^{\circ} \mathrm{C}$ ).

Поверхностную стерилизацию проростков проводили с использованием различных концентраций раствора «Белизны», содержащей активный хлор (концентрация гипохлорита натрия в «Белизне» составляла $0.80 \%)$.

Промытые водой проростки родиолы розовой переносили в $70 \%$ раствор этанола на 30 секунд и затем в раствор «Белизны». Были проанализированы растворы с концентрацией гипохлорита натрия: $0.10 \%, 0.13 \%, 0.16 \%, 0.20 \%, 0.40 \%$. Время экспозиции в соответствующих растворах - 20 минут. Затем экспланты трехкратно промывали автоклавированной дистиллированной водой и высаживали на питательную среду.

Разработанные схемы стерилизации проростков родиолы розовой приведены в таблице 1.

Таблица 1. Схемы стерилизации проростков родиолы розовой

\begin{tabular}{|c|c|c|}
\hline \multirow{2}{*}{ Номер схемы } & \multicolumn{2}{|c|}{ Концентрация стерилизующего агента и время выдержки } \\
\hline & Этиловый спирт & Гипохлорит натрия \\
\hline 1 & \multirow{5}{*}{$70 \%, 30$ секунд } & 0.10\%, 20 минут \\
\hline 2 & & 0.13\%, 20 минут \\
\hline 3 & & 0.16\%, 20 минут \\
\hline 4 & & 0.20\%, 20 минут \\
\hline 5 & & 0.40\%, 20 минут \\
\hline
\end{tabular}

В качестве питательной среды для введения в культуру in vitro проростков родиолы розовой использовали среду Мурасиге и Скуга (МС) с добавлением 30 г/л сахарозы и 8 г/л агар-агара. Значение $\mathrm{pH} 5.8$.

Полученные данные анализировали с использованием пакета компьютерных программ GraphPad Prism 5. Рассчитывали средние значения и стандартные отклонения. 
Результаты и обсуждение. По полученным данным можно сказать, что стевиозид действительно стимулировал прорастание семян родиолы розовой относительно контроля. На 3-й день наблюдений только в опытных вариантах с замачиванием в растворе стевиозида обнаружили проросшие семена. Во всех опытных вариантах проросло $30 \%$ семян кроме варианта с замачиванием на 24 ч (10\%). Контрольные семена прорастали постепенно, начиная с 7-го дня наблюдений, к 60-му дню процент проросших семян составил $30 \%$. Аналогичный результат через 2 месяца был зафиксирован в варианте с замачиванием семян в растворе стевиозида на 6 ч.

При 24 ч обработке процент прорастания был минимальный, а по достижении 7-дневного возраста проростки погибали. Более длительные экспозиции семян родиолы розовой в растворе стевиозида, по-видимому, оказывают ингибирующий эффрект.

По нашим данным максимальный стимулирующий прорастание эффрект оказывала обработка семян стевиозидом в течение 3-х и 12-и часов, значение показателя составило $40 \%$. Однако данные варианты обработки семян стевиозидом не одинаково влияют на рост проростков. Несмотря на то, что оба варианта стимулируют рост надземной части проростков относительно контроля (рисунок 1А), увеличение длины подземной части зафриксировано только при кратковременной обработке в течение 3 часов (рисунок 1Б).

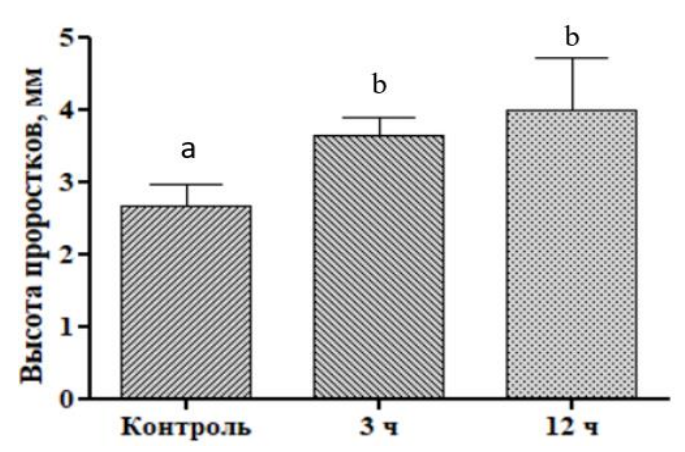

A

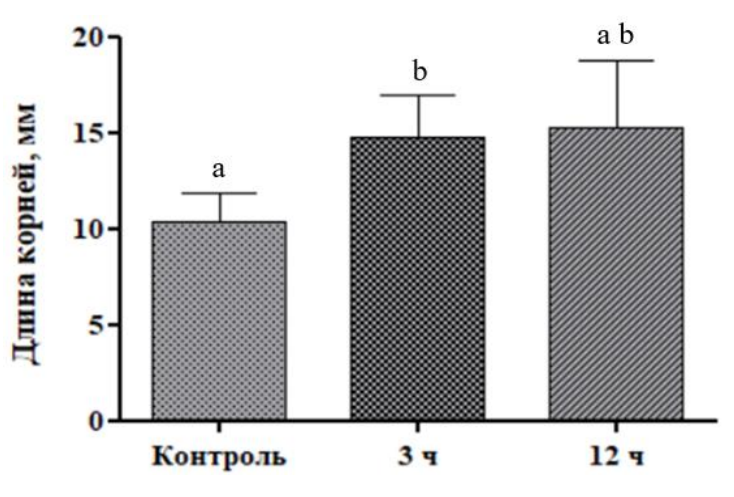

Б

Рис. 1. Морфометрические показатели проростков родиолы розовой, обработанной перед посадкой стевиозидом $\left(10^{-8} \mathrm{M}\right)$ : А - Длина надземной части на 30-й день выращивания, мм; Б - Длина подземной части на 30-й день выращивания, мм

По литературным данным подбор эффективного протокола стерилизации эксплантов родиолы розовой является одной из ключевых проблем при разработке биотехнологических подходов размножения растения или получения каллусных культур, и в каждом случае время и концентрацию необходимо подбирать экспериментально [1], [6]. Для подбора оптимального протокола стерилизации проростков родиолы розовой раствором «Белизны» в сочетании с выдержкой в этиловом спирте разработали четыре схемы, представленные в таблице 1. При использовании раствора «Белизны» в качестве стерилизующего агента целесообразно стремиться к снижению концентрации раствора, компенсируя это увеличением продолжительности стерилизации [7]. Результаты предварительных экспериментов свидетельствуют о том, что, по-видимому, обработка раствором «Белизны» с содержанием гипохлорита натрия $0.40 \%$ является губительной для проростков.

Таким образом, схема эксперимента по стерилизации проростков включала промывку проточной водой в течение 10 минут, выдержку в 70\% этиловом спирте 30 секунд и в растворах «Белизны» с содержанием гипохлорита натрия 0.10\%, 0.13\%, 0.16\% или 
0.20\% в течение 20 минут с последующей трехкратной промывкой автоклавированной дистиллированной водой. Как видно из рисунка 2, наибольшую эффективность показала схема с использованием $0.16 \%$ раствора гипохлорита натрия, стерильность жизнеспособных эксплантов составила $81 \%$.

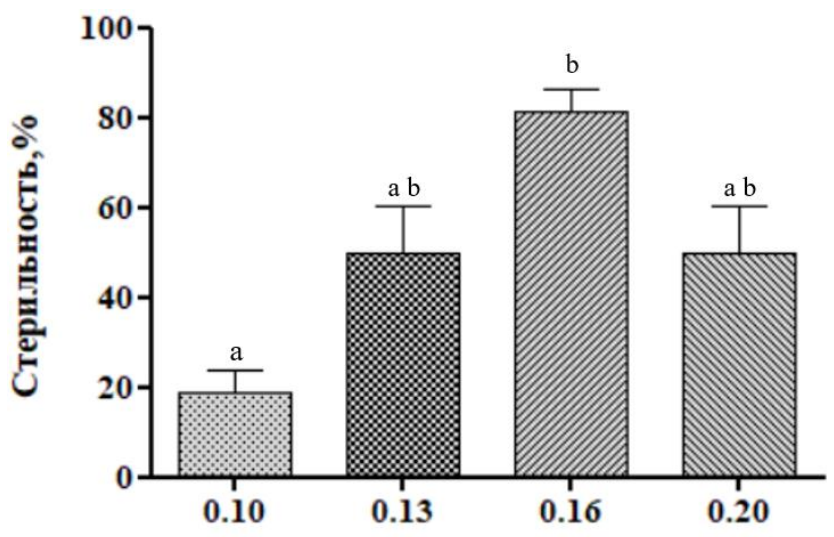

Концентрации гипохлорита натрия,\%

Рис. 2. Процент стерильности жизнеспособных проростков родиолы розовой в культуре in vitro.

Полученные проростки после стерилизации согласно схеме 3 (таблица 1) переносили на безгормональную питательную среду MC и выращивали в течение 3-х месяцев в растильне. Затем провели повторный морфологический анализ контрольных и опытных проростков родиолы розовой.

Результаты измерений морфологических параметров родиолы на 3-м месяце культивирования представлены в таблице 2.

Таблица 2. Морфологические параметры родиолы розовой в культуре in vitro, срок культивирования - 3 месяца

\begin{tabular}{|l|l|l|}
\hline Морфологические параметры & Контроль (вода) & Опыт (3 ч стевиозид) \\
\hline Высота побегов, см & $2.93 \pm 2.32$ & $2.65 \pm 1.33$ \\
\hline Длина корней, см & $2 \pm 0.71$ & $2.13 \pm 0.48$ \\
\hline Количество побегов, шт & $1.5 \pm 0.71$ & $2.5 \pm 1.29$ \\
\hline Количество корней, шт & $29 \pm 2.83$ & $46.5 \pm 11.36$ * \\
\hline Количество листьев/растение, шт & $10.5 \pm 2.12$ & $23.5 \pm 5.80$ * \\
\hline
\end{tabular}

Как видно из таблицы 2, длина надземной и подземной части контрольных и обработанных стевиозидом растений не отличается, однако исследуемый гликозид вызывает увеличение количества листьев и корней у проростков родиолы розовой в культуре in vitro. По-видимому, биомасса опытных растений оказывается выше контрольных, что может позволить значительно повысить коэффрициент размножения Rhodiola rosea L. B культуре in vitro.).

Таким образом, показано, что стевиозид в концентрации $10^{-8} \mathrm{M}$ сокращает время прорастания семян родиолы розовой. Однако только 3-х часовая предпосевная обработка данным гликозидом повышает всхожесть семян, стимулирует рост надземной и под- 
земной части проростков. Установлено, что наиболее эфффективная схема для стерилизации проростков родиолы: сочетание $0.16 \%$ раствора гипохлорита натрия с предварительной обработкой $70 \%$ этиловым спиртом. Показано, что полученные in vitro растения родиолы розовой из обработанных стевиозидом проростков фрормируют большее количество листьев и корней, чем контрольные растения.

\section{Литература}

1. Tasheva K. Bulgarian golden root in vitro cultures for micropropagation and reintroduction // Open Life Sciences. 2010. V. 5(6). P. 853-863. DOI: 10.2478/s11535-010-0092-3

2. Павлова П. А. Интродукционное испытание Rhodiola rosea L. в якутском ботаническом саду // Вестник КрасГАУ. 2015. №.4. С. 94-98.

3. Андросова Д. Н. Эколого-биологические особенности прорастания семян травянистых растений природной фрлоры Центральной Якутии при интродукции : авторефр. дис. на соиск. уч. ст., канд. биол. наук / Д. Н. Андросова, 2021. - 181 с.

4. Савченко О. М. Влияние стратификации и регуляторов роста на энергию прорастания и всхожесть трех видов рода родиола (Rhodiola L.) // Биология растений и caдоводство: теория, инновации. 2018. C. 112-116. DOI: 10.25684/NBG.scbook.146.2018.16

5. Ogorodnova U. A. The chemical structure of steviol-glycosides as base of biological activity // International Journal of Pharmacy \& Technology. 2016. V .8. P. 14936-14944.

6. Galikhanova U. A. Stevioside-induced molecular heterogeneity and lectin activity at low positive temperatures // Caspian J. Environ. Sci. 2020. Vol. 18. №5. P. 473-480. DOI: 10.22124 / CJES.2020.4473

7. Erst A. In vitro propagation of rare species Rhodiola rosea from Altai Mountains // Turczaninowia. 2018. Vol. 21. C. 78-86. DOI: 10.14258/turczaninowia.21.4.9

8. Лебедь М. Б. Исследование эффрективности различных способов стерилизации эксплантов картофеля при микроклональном размножении // Успехи современного естествознания. 2019. № 9. С. 26-30. 